\title{
Cissus quadrangularis Linn. Extract Reduces High Glucose Induced Inhibition of In Vitro Proliferation and Matrix Mineralization in MG-63 Cells
}

\author{
Madhu Gupta and Md. Arshad \\ Department of Zoology, University of Lucknow, Lucknow-226007 (U.P.), India
}

(Received: June 26, 2017; Accepted: December 10, 2017; Published (web): December 23, 2017)

\begin{abstract}
The aim of this study was to evaluate the effect and mechanism of action of ethanolic extract of Cissus quadrangularis Linn. stem in an in vitro system using MG-63 (osteoblast-like) cells. Cells were pre-exposed to high glucose $(45 \mathrm{mmol} / \mathrm{l})$. Insulin was used as positive control. To determine whether $C$. quadrangularis $(C Q)$ extract could prevent hyperglycaemia induced oxidative stress, and apoptosis we performed reactive oxygen species generation using 2', 7'-dichlorofluorescin diacetate and propidium iodide staining for apoptosis. For cell proliferation, we carried out cell viability (MTT) assay. Further, alkaline phosphate assay and alizarin staining were done to study the matrix mineralization. High glucose $(45 \mathrm{mmol} / \mathrm{l})$ significantly $(P<0.001)$ inhibited the cell viability and matrix mineralization, and induced apoptosis as compared to physiological control. C. quadrangularis extract as well as insulin treatment significantly ( $\mathrm{p}<0.001$ versus high glucose) restored the cell viability, cell differentiation and bone nodule formation. Thus, ethanolic extract of $C$. quadrangularis stem prevents the antiproliferative effect of high glucose.
\end{abstract}

Key words: High glucose, apoptosis, cell viability, MG-63, Cissus quadrangularis.

\section{INTRODUCTION}

Diabetes mediated hyperglycemia increases the risk of osteoporosis and other pathological complications in bone. ${ }^{1,2}$ Bone loss during type I diabetes mellitus is accompanied by lack of insulin due to the inactivation and destruction of pancreatic beta cells. ${ }^{3}$ This in turn is followed by elevated blood glucose which causes osmotic shock, altered proliferation and induced apoptosis of bone cells with reduced bone remodelling. ${ }^{4}$ Cissusquadrangularis Linn. (CQ) (family - Vitaceae) commonly known as Hadjod (bone healer) in Indian subcontinents is well known for its anti-resorptive and bone healing properties $^{5}$. CQis very well demonstrated for its osteogenic activity for estrogen deficient osteoporosis. $^{6,7}$ The ethanol extract of stem of $C Q$ is a rich source of calcium ion and has the ability to

Correspondence to: Madhu Gupta Cell: +91 7309721312, Fax: +91 5222740230 ,

E-mail: madhugupta2010@gmail.com

Dhaka Univ. J. Pharm. Sci. 16(2): 159-164, 2017 (December) form bioorganic calcite crystals. ${ }^{8}$ Effect of $C Q$ is yet to be explored on bone cells of diabetic model. So we evaluated in vitro efficacy of $C Q$ extract and its potential to ameliorate high glucose-induced cell injuries in human osteoblast like MG-63 cells preexposed to high glucose. Along with, we examined the mechanism of its action in relation to the involvement of reactive oxygen species, biochemical and cellular markers of proliferation, apoptosis and matrix mineralization.

\section{MATERIALS AND METHODS}

Chemicals and reagents. Minimum Essential Medium (MEM), Foetal Bovine Serum (FBS), sodium pyruvate, non-essential amino acids, sodium bicarbonate, L-glutamine, antibiotic solution (streptomycin/ penicillin), ascorbic acid, alizarin red powder, 3-(4,5-dimethylthiazol-2-yl)-2,5-diphenyltetrazolium bromide (MTT) dye and dexamethasone were purchased from HIMEDIA Laboratories Pvt. 
Ltd., Mumbai, India. Cetylpyridinium chloride (CPC) was purchased from Sisco Research Laboratories Pvt. Ltd., Mumbai, India. Insulin used was $100 \mathrm{IU} / \mathrm{ml}$ of Huminsulin (regular) from Eli Lilly and Company, India. 2',7'-Dichlorofluorescin diacetate (DCFHDA), Propidium iodide (PI), $\beta$-glycerophosphate was from Sigma-Aldrich Inc., St. Louis, USA. Dimethyl sulfoxide (DMSO) was from Merck Specialities Pvt. Ltd., Mumbai, India. All the other reagents were of analytical grade.

Collection of plant and preparation of extract. The stem of $C$. quadrangularis $(C Q)$ was collected by the Department of Botany, University of Lucknow, India in month of Juneand systematically identified by Muhmmad Arif, Assistant Professor, Department of Pharmacognosy, Integral University, Lucknow. Voucher specimen No. IU/PHAR/HRB/ 14/06, was deposited in the same department for reference. Shade dried parts of the plant was finely powdered and then subjected to ethanolic extraction using $95 \%$ ethanol in a Soxhlet extractor.

Cell culture. MG-63 cell - a human osteoblast like cell line was procured from National Centre of Cell Science (NCCS), Pune, India. Cells were cultured in MEM medium containing 10\% FBS and $1 \%$ antibiotic solution (streptomycin and penicillin). Cells were grown at $37^{\circ} \mathrm{C}$ in a humidified air containing $5 \% \mathrm{CO}_{2}$ till confluence.

Experimental setup. The osteoblasts were divided into six groups: physiological control $(\mathrm{Ph}$. Ctrl) in which the cells were maintained with physiological glucose concentration $(5.5 \mathrm{mmol} / \mathrm{l})$; a negative control high glucose (HG) group in which the cells were exposed to high glucose $(=45 \mathrm{mmol} / \mathrm{l}$ was the concentration at which $\sim 50 \%$ cell death observed). ${ }^{9}$ In groups 1,10 and 50 means cells were pre-exposed to high glucose for $24 \mathrm{~h}$ before treatment and then treated with $1 \mu \mathrm{g}, 10 \mu \mathrm{g}$ and $50 \mu \mathrm{g}$ of $C Q$ extract, respectively and insulin (INS) group in which HG pre-exposed cells were treated with insulin (0.5IU).

MTT assay for cell proliferation. MTT assay was performed to evaluate cell viability of MG-63 in different treatment groups. Cells were cultured in 96- well plates at a density of $1.2 \times 10^{6}$ cells/well according to a previously described protocol. ${ }^{10}$ After $44 \mathrm{~h}$ of treatments, the cells were exposed to10 $\mu \mathrm{l}$ of MTT solution (5 mg/ml stock solution) in each well and re-incubated for $4 \mathrm{~h}$ at $37^{\circ} \mathrm{C}$ until formazan blue crystal developed. Media was discarded from each well and $100 \mu \mathrm{l}$ of DMSO was added to dissolve formazan crystals for $10 \mathrm{~min}$ at $37^{\circ} \mathrm{C}$. The absorbance was recorded at $540 \mathrm{~nm}$ by microplate reader (BIORAD-680) and relative percentage cell viability was evaluated using the formula:

Cell viability $=\frac{A_{T}-A_{0}}{A_{C}-A_{0}} \times 100$

Where $A_{T}$ is absorbance of treated, $A_{0}$ is absorbance of blank and $A_{C}$ is absorbance of physiological control.

Propidium Iodide staining for apoptosis detection. This staining was based on selective labelling of cells in very late apoptotic phase or necrotic cells by propidium iodide (PI). ${ }^{11}$ Briefly, the monolayer washed thrice with PBS, fixed in $4 \%$ paraformeldehyde for $10 \mathrm{~min}$ and $100 \mu \mathrm{l}$ of PBS was added. $1 \mu \mathrm{l}$ of PI dye $(5 \mathrm{mg} / \mathrm{ml})$ was loaded in each well of 96 well plates and incubated for another 10 min. Cells were visualized under fluorescence microscope (Nikon, ECLIPSE Ti-Series) for determination of morphological changes. For quantification, percentages of apoptotic cells were calculated as the ratio of cells showing bright red fluorescence (PI positive) to the total number of cells (PI positive + PI negative).

Alkaline phosphatase (ALP) Assay. ALP activity was measured according to Faucheux et al, (2008). MG- 63 cells were plated at $5 \times 10^{3}$ cells in $100 \mu \mathrm{l}$ ALP media (MEM containing $10 \mathrm{mmol} / \mathrm{l} \beta$ glycerophosphate and $50 \mu \mathrm{g} / \mathrm{ml}$ ascorbic acid) per well in a 96 well plate and incubated for $24 \mathrm{~h}$. After incubation, cells were pre-exposed to $\mathrm{HG}$ and treated with 1,10 and $50 \mu \mathrm{g}$ of $C Q$ extract and $0.5 \mathrm{IU}$ of insulin. Beside this a physiological control group was maintained at $5.5 \mathrm{mmol} / \mathrm{l}$ of glucose for comparison purpose. After treatment plates were washed with PBS and kept at $-70^{\circ} \mathrm{C}$ for 20 min. Plates were taken out and then kept at $37^{\circ} \mathrm{C}$ for $10 \mathrm{~min} .75 \mu \mathrm{l}$ of chilled pNPP substrate was added to plates (Substrate as 9.4 
$\mathrm{mg} \mathrm{pNPP} / 5 \mathrm{ml}$ of milliQ water). Cells were incubated at $37^{\circ} \mathrm{C}$ for half an hour for color development. Finally, absorbance was taken at $405 \mathrm{~nm}$ in multi well ELISA plate reader (BIORAD 680).

Mineralization assay. Mineralization assay was performed according to published method. Briefly, upon $80 \%$ confluence in 12 well plates, cells were cultured in differentiation medium containing 10 $\mathrm{mmol} / \mathrm{l} \beta$-glycerophosphate, $50 \mu \mathrm{g} / \mathrm{ml}$ of ascorbic acid and $10^{-7} \mathrm{~mol} / \mathrm{l}$ dexamethasone. Treatment groups were same as in above experiments. Culture media was refreshed every second day till two weeks. On day 15 , media was aspirated and cells were washed twice with PBS, fixed in $10 \%$ formalin for half an hour, and stained with $40 \mathrm{mmol} / \mathrm{l}$ alizarin red stain for $10 \mathrm{~min}$. Excess stain was removed by washing 5 times with distilled water. Cells were analyzed under inverted microscope and images were taken (Nikon, ECLIPSE Ti-Series). For quantification purpose, alizarin red S-calcium complex then incubated with $10 \% \mathrm{CPC}$ in $10 \mathrm{mmol} / \mathrm{l}$ sodium phosphate for 30 min. The concentration of released alizarin red stain was determined by taking absorbance at $610 \mathrm{~nm}$ in a multi-well ELISA plate reader.

DCFH-DA staining for reactive oxygen species (ROS). Percentage of cells generating ROS can be assessed by staining cells with DCFH-DA. ${ }^{11}$ The principle includes diffusion of DCFH-DA, deacetylation into DCFH and its oxidation into highly fluorescent DCF in the presence of ROS. Freshly prepared $10 \mathrm{mmol} / \mathrm{L}$ DCFH-DA was loaded in 24 well plates and incubated for 30 minutes at $37^{\circ} \mathrm{C}$. After cells were visualized under fluorescence microscope (Nikon, ECLIPSE Ti-Series) percentage of ROS generating cells to that of total number of cells was calculated.

Statistical analysis. All the data were presented as the means \pm S.D. of results achieved after experiment. Statistical analysis was performed by one way ANOVA method followed by the Tukey's test of significance using Graph Pad Prism 5.0 software. Probability values of $\mathrm{p}<0.05$ were considered statistically significant.

\section{RESULTS AND DISCUSSION}

When data from cell proliferation assay (Figure 1) and apoptosis (Figure 2) were compared together, an inverse relationship between proliferation and percent apoptotic cells was found. The rate of proliferation was significantly $(P<0.001)$ decreased to $38.0 \%$ in $\mathrm{HG}$ group as compared to physiological control (Figure 1). $C Q$ extract in all its groups normalized the effect of $\mathrm{HG}$ and restored the proliferation rate near to the physiological control. Cell viability was found to increase to $158.0 \%$ in the group treated with $50 \mu \mathrm{g}$ of $C Q$ extract, suggesting that the high dose is more effective in reducing hyperglycaemia-induced inhibition of cell proliferation. When compared with insulin-treated group, $C Q$ extract at $50 \mu \mathrm{g}$ dose was found to be more effective ( $p<0.05$ versus insulin). In HG group, increased rate of apoptosis was observed $(55.1 \% ; \mathrm{p}<0.001)$. While in all the treatment groups, percentage of apoptotic cells was reduced $(\mathrm{p}<0.001)$ (Figure 2).

The ALP activity was significantly $(\mathrm{p}<0.001)$ lowered in HG group as compared to physiological control. The protective effect of insulin and $C Q$ extract was evident with significant increase $(\mathrm{p}<$ 0.001) in ALP activity in all of these groups (Figure 3). A significant $33.0 \%, 48.0 \%$ and $56.0 \%$ increase in ALP activity in $C Q$ treated groups at 1,10 and $50 \mu \mathrm{g}$ respectively and $48 \%$ increase in insulin treated group was observed when compared with HG.

Mineralization nodule formation was significantly $(\mathrm{p}<0.001)$ reduced in HG by $84.5 \%$ as compared to physiological control. Rate of mineralization was significantly $(\mathrm{p}<0.001)$ increased in $1,10,50 \mu \mathrm{g} C Q$ and insulin treated groups by $73.8 \%, 84.7 \%, 85.9 \%$, and $80.0 \%$, respectively when compared to HG group (Figure 4). The ROS generation was assessed by DCF fluorescence (Figure 5). The percentage of cells showing fluorescence was quite high in HG (73.0\%) than rest of the groups $(\mathrm{p}<0.001)$. The percentage of ROS generating cells was reduced to $1.1 \%$ in $50 \mu \mathrm{g} C Q$ treated group showing the least number of fluorescence generating cells. 
High glucose attenuates osteoblastic proliferation via three mechanism- (i) osmotic shock $^{4,12}$ (ii) enhanced ROS generation thus causing oxidative stress $^{13}$, and (iii) inducing apoptosis. ${ }^{12} C Q$ treated groups showed dose dependent enhancement in cell proliferation thus reversing the deleterious effects of high glucose. $C Q$ at high dose $(50 \mu \mathrm{g})$ showed marked increase in cell proliferation with enhanced

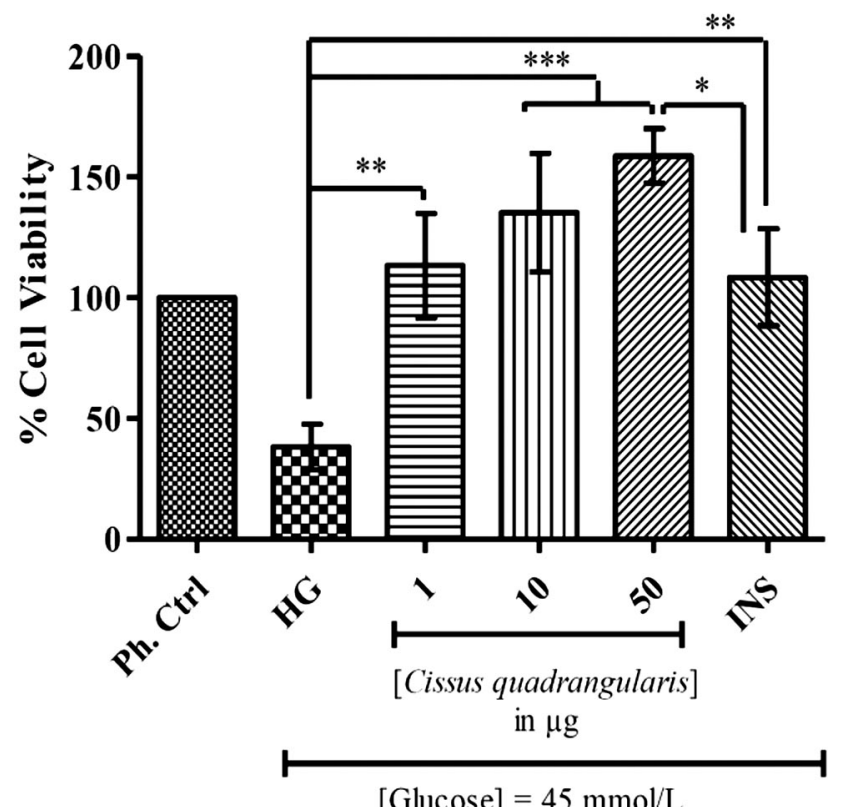

Figure 1.Anabolic action of Cissus quadrangularis extract $(C Q)$ on osteoblast like MG-63 cells. Cells were preincubated with high glucose $(\mathrm{HG})=45 \mathrm{mmol} / \mathrm{L}$ and then treated with insulin (INS) $=0.5 \mathrm{IU}$ and $1,10,50 \mu \mathrm{g}$ concentrations of $C Q$ extract Ph. Ctrl simply represent physiological control containing $5.5 \mathrm{mmol} / \mathrm{l}$ glucose. MTT assay was performed as mentioned in material and method section. Data represents average of three independent experiments and are expressed as mean $\pm \mathrm{SD},{ }^{* * *} \mathrm{p}<0.001 ; * * \mathrm{p}<0.01 ;{ }^{*} \mathrm{p}<$ 0.05 .
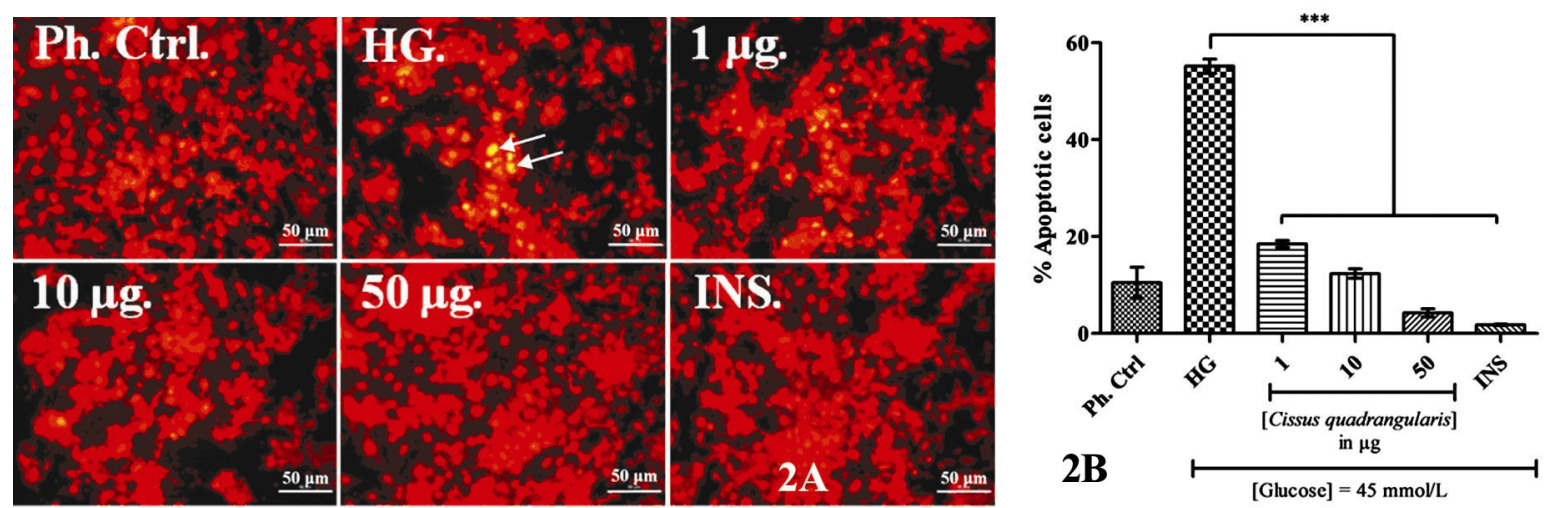

Figure 2. Cissus quadrangularis extract (CQ) rescue MG-63 cells from high glucose induced apoptosis. (A) After treatment cells were stained with propidium iodide (PI) which is permeable only to cells in late apoptotic phase or dead cells. White arrows indicate the cells showing bright red fluorescence of PI are actually either cells in late apoptosis or dead cells. Images were snapped with Nikon phase contrast with a fluorescence microscope (original magnification: 20X; Scale bar: $50 \mu \mathrm{m}$ ). (B) Results are represented as percentage of apoptotic cells and values are expressed as mean $\pm \mathrm{SD}$ of three independent experiments, $* * * \mathrm{p}<0.001$. 


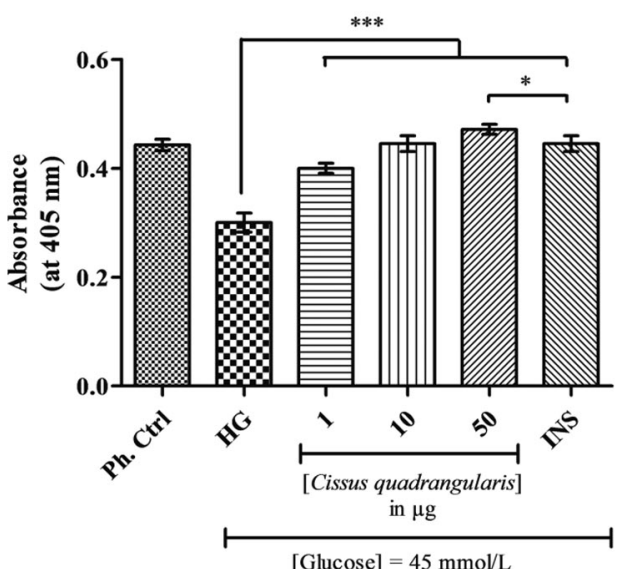

Figure 3. Effect of Cissus quadrangularis extract (CQ) on ALP activity in MG-63 cells. Data was quantified spectrophotometrically at 405 $\mathrm{nm}$. Values are obtained from three independent experiments and expressed as mean $\pm \mathrm{SD}, * * * \mathrm{P}<0.001 ; * \mathrm{P}<0.05$.
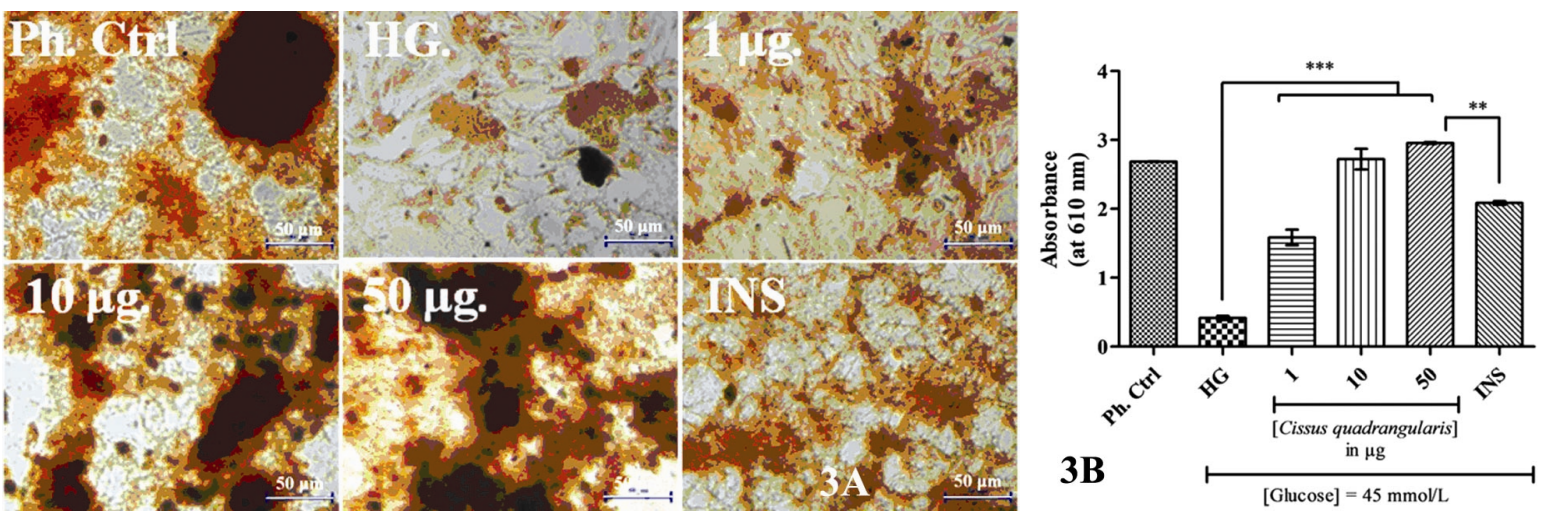

Figure 4. Extract of Cissus quadrangularis extract $(C Q)$ induces extracellular matrix mineralization. (A) Photographs showing extracellular matrix mineralization and calcium deposition upon staining with alizarin red S which form complex with calcium. (B) After 14 days of incubation, stain was extracted with CPC and absorbance measured spectrophotometrically. Data represented as mean \pm SD of three independent experiments, $* * * \mathrm{p}<0.001$.
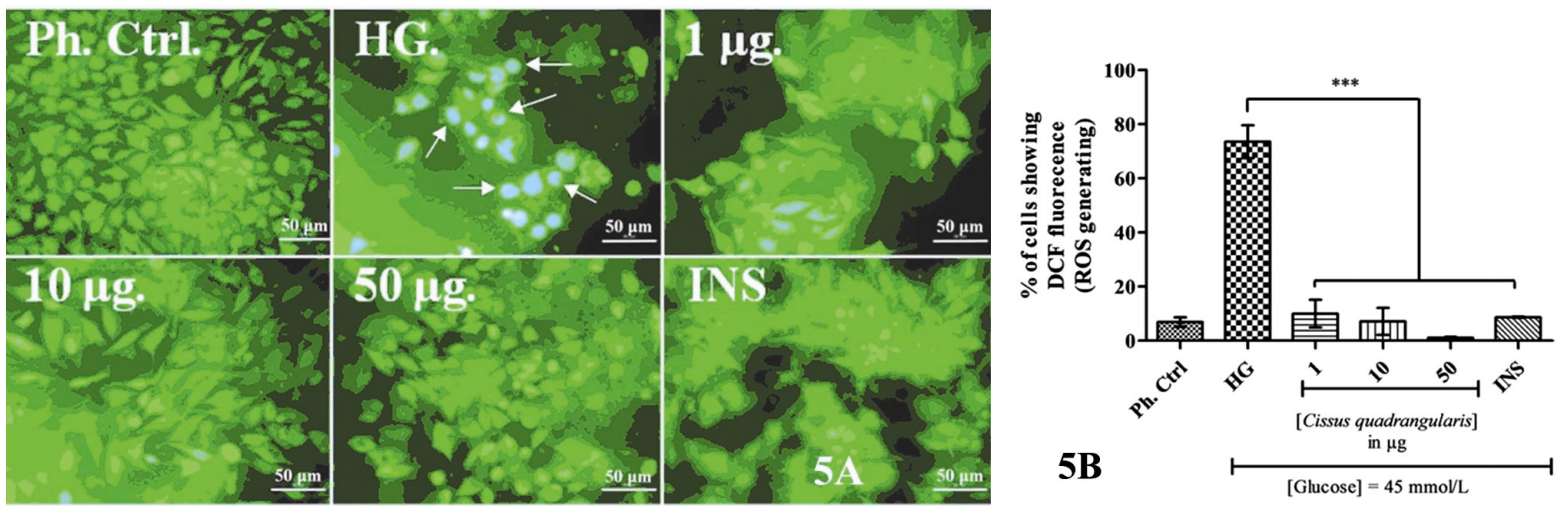

Figure 5. Antioxidative properties of Cissus quadrangularis extract $(C Q)$. (A) Photomicrographs showing intracellular ROS generation induced by high glucose are restored to the normal level after treatment. Red arrows indicated cells generating DCF which fluoresce green after reaction with ROS. Images were snapped with Nikon phase contrast with a fluorescence microscope (original

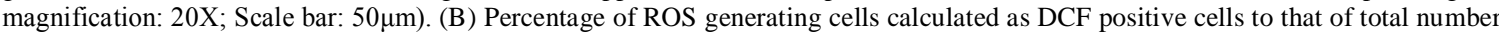
of cells. The experiment was repeated thrice and cell counting was done using NIS Elements Documentation software provided with the microscope. Values are obtained as mean $\pm \mathrm{SD}, * * * \mathrm{p}<0.001$ 
rate of ALP activity which in-turn leads to increased calcium deposition and mineralization nodule formation (Figure 3 and 4). The high dose of $C Q$ markedly reduced the percentage of apoptotic cells. A reduction in percentage of DCF fluorescent cells is suggestive of antioxidative effect of CQ extract. High dose of $C Q$ was most efficient in protecting the cells from HG induced injury. $C Q$ extracts have been shown to possess both osteoblastogenic ${ }^{14}$ as well as antiosteoporotic properties. ${ }^{6}$ The restorative effect of insulin was similar to physiological control group in all experiments. In the present investigation we reported that the $C Q$ extract is effective in reducing high glucose-induced severity in osteoblast like MG63 cells by increasing the proliferation and matrix mineralization of cells and simultaneously reducing oxidative stress and thereby controlling apoptosis. Therefore, it is concluded that $C Q$ could be a better alternative medicine for diabetes and related osteopathy.

\section{ACKNOWLEDGEMENTS}

Authors are thankful to Council of Scientific and Industrial Research (CSIR), New Delhi, India for providing financial assistance to this work (File no. 09/107(350)/2010-EMR-I). Authors have no conflicts of interest.

\section{REFERENCES}

1. Silva, M.J., Brodt, M.D., Lynch, M.A., Mckenzie, J.A., Tanouye, K.M., Nyman, J.S. and Wang, X. 2009. Type 1 diabetes in young rats leads to progressive trabecular bone loss, cessation of cortical bone growth, and diminished whole bone strength and fatigue life. J. Bone. Min. Res. 24, 16181627.

2. García-Hernández, A., Arzate, H., Gil-Chavarría, I., Rojo, R. and Moreno-Fierros, L. 2012. High glucose concentrations alter the biomineralization process in human osteoblastic cells. Bone 50, 276-288.

3. Nicodemus, K.K. and Folsom, A.R. 2001. Type 1 and type 2 diabetes and incident hip fractures in postmenopausal women. Diabetes Care 24, 1192-1197.
4. Botolin, S. and McCabe, L.R. 2006. Chronic hyperglycemia modulates osteoblast gene expression through osmotic and non-osmotic pathways. J. Cell. Biochem. 99, 411-424.

5. Potu, B.K., Rao, M.S., Nampurath, G.K., Chamallamudi, M.R., Prasad, K., Nayak, S.R., Dharmavarapu, P.K., Kedage, V. and Bhat, K.M. 2009. Evidence-based assessment of antiosteoporotic activity of petroleum-ether extract of Cissusquadrangularis Linn. onovariectomy-induced osteoporosis. Ups. J. Med. Sci. 114, 140-148.

6. Muthusami, S., Senthilkumar, K., Vignesh, C., Ilangovan, R., Stanley, J., Selvamurugan, N. and Srinivasan, N. 2011. Effects of Cissusquadrangularis on the proliferation, differentiation and matrix mineralization of human osteoblast like SaOS-2 cells. J. Cell. Biochem. 112, 1035-1045.

7. Banu, J., Varela, E., Bahadur, A.N., Soomro, R., Kazi, N. and Fernandes, G. 2012. Inhibition of bone loss by Cissusquadrangularis in mice - a preliminary report. $J$. Osteoporos. 2012, 1-10.

8. Sanyal, A., Ahmad, A. and Sastry, M. 2005. Calcite growth in Cissusquadrangularis plant extract, a traditional Indian bone-healing aid. Curr. Sci. 89, 1742-1745.

9. Gupta, M., Rawat, V. and Arshad, M. 2014. A Study on the Effect of High Glucose on Osteoblasts like Cell Proliferation and Apoptosis. Int. J. Pharm. Life. Sci. 5, 3862-3866.

10. Faucheux, C., Verron, E., Soueidan, A, Josse, S. and Arshad, M. 2008. Controlled release of bisphosphonate from a calcium phosphate biomaterial inhibits osteoclasticresorption in vitro. J. Biomed. Mater. Res. A.89, 46-56.

11. Kaviarasan, S., Ramamurty, N., Gunasekaran, P., Varalakshmi, E. and Anuradha, C.V. 2006. Fenugreek (Trigonellafoenumgraecum) seed extract prevents ethanolinduced toxicity and apoptosis in Chang liver cells. Alcohol. Alcohol. 41, 267-273.

12. Balint, E., Szabo, P., Marshall, C.F. and Sprague, S.M. 2001. Glucose-induced inhibition of in vitro bone mineralization. Bone 28, 21-28.

13. King, G.L. and Loeken, M.R. 2004. Hyperglycemia-induced oxidative stress in diabetic complications. Histochem. Cell. Biol. 122, 333-338.

14. Parisuthiman, D., Singhatanadgit, W., Dechatiwongse, T. and Koontongkaew, S. 2009. Cissusquadrangularis extract enhances biomineralization through up-regulation of MAPKdependent alkaline phosphatase activity in osteoblasts. In Vitr. Cell Dev. Biol. Anim. 45, 194-200. 